\title{
Enrich the Knowledge of Future Professions by Coloring Activities
}

\author{
Novena Ulita ${ }^{1}$, GhazyTaufiq Alhakim² ${ }^{2}$ Fina Melisa ${ }^{3}$ \\ UniversitasMercuBuana \\ E-mail :novena.ulita@mercubuana.ac.id', ghazytaufiqalha@gmail.com², finamelisaur@gmail.com³
}

\begin{abstract}
This creative activity is a part of a community service program. It is done in Ruang Publik Terpadu Ramah Anak (RPTRA) Meruya Selatan. The purpose of this activity are : encouraging student motivation in learning, directing the students to be focused on their goals and, shaping student's positive perceptions in terms of improving student's school motivation as well as making playful activity in their free time during the Covid-19 pandemic. The method used are : qualitative descriptive method, presentation and role play method, and question and answer method. The objective of this activity are for students and their mother in RPTRA Meruya Selatan. This activity found 3 main issues, which are : low confidence, having no purpose and not aware of the importance of going to school, and difficulties of communicating and socializing. By this activity, both mother and their child (student) are able to interact, socialize, as well as sharing information regarding the future profession options while discussing upon their coloring activity. Illustrations come as an instillation of students' positive perceptions towards various profession that are introduced by their mothers. Coloring activity could stimulate student's brain work in terms of remembering their chosen profession in the future.
\end{abstract}

Keywords: Coloring, Discussing, Coloring Book, School Motivation.

DOI: $10.7176 / \mathrm{ADS} / 91-06$

Publication date:March $31^{\text {st }} 2021$

\section{INTRODUCTION}

Education issue has always been an interesting discussion in Indonesian society. There are a lot of talks, such as curriculum changing, learning evaluation system and rules, budget distribution, and learning implementation. Even more the new lead in Indonesian Ministry of Education and Culture, Bapak Nadiem Makarim, could also be a topic.

Education is all the basis of value that instilled in society. As the first pillar in life, education must come first and need to be considered for building a nation. Furthermore, it needs a system for setting the administration of education by the people in charge, so the rule made could accommodate all related parties. By this case, both of the administration and the objective of education could be equally touched by the whole community (Fahrudi, 2016). Meanwhile, the fact of education in Indonesia have thousand of never ending problems.

Curriculum changing always been a number one topic to discuss among the people in charge in education expert, in many ways. However, according to Bapak Nadiem Makarim as the Indonesian Minister of Education and Culture, "The most important part in education is the teacher role. It has to be equally considered as the curriculum, because value transferring and learning process in terms of curriculum understanding to the students all depends on the quality of the teacher," He said after handing over the position on 2019, $23^{\text {rd }}$ October (CNN,2019).

Curriculum determination that decided by other's country succession of implementation going to be difficult to apply in Indonesia which the people have a different character than the people where the curriculum adopted. This is the reason of unequal human resources and infrastructure in Indonesia been another topic of Indonesian education. The main philosophy in terms of education understanding must be : formulate the education, setting the national standard system of education, and the essence of human by having Pancasila's understanding on it (Suroto, 2014).

By above description, education issue is important to be considered for looking the solution of society's issue. The main issue in education that are teacher role and curriculum have to be the top priority to be solved, particularly in big cities which being the example of education implementation by people in the lower regional level. Other than that, in lower regional level, education issue expand to an equality issue of education distribution. Teacher role and curriculum issue have to be solved soon, so that the education administration able to raising the generation who are ready for challenge in the future. 
The unsolved issue of education administration impact to student's interest and motivation in terms of fulfill the learning process in class. The limited teacher quality and curriculum that is not transferred in a right way made the student lost the direction of achieving the real target of education. The target of education itself being blur and the student confuse in deciding their future. In fact, the target is important, due to it helps themselves to achieving their goal in the future. The target is not supposed to based on the learning evaluation indicator only which is just hold by the national level society. The real target of education is preparing someone to having a creative skill, a certain proficiency, and a character value, so that they could compete with others and being the problem solver at society in facing the challenge in the future.

That is the reason of why the author as a teacher, specifically focusing the interest to the nowadays education situation, in order to contribute a solution for education issue in Indonesia, particularly for people in capital city, and specifically in Visual Communication Design study major.

By above analysis, teacher role and curriculum come as two important thing that need to be considered, but both of them could be solved at the level of policy system. Meanwhile, author try a chance to contribute a little solution for the issue itself in Indonesia. As a teacher we are asked to be creative in finding a solution, particularly for education issue. Teacher role referring to the Tri Dharma of university for serving the community, which is will be good if started from the smallest society, that is district and sub district.

In author's opinion, the presence of RPTRA in Jakarta, as a capital city is a bright decision. The density of capital city needs an open space for child so they could socializing, playing, and learning by their surroundings which in order to having a balance intelligence. RPTRA could also being a society's space in order to contribute in improving the quality of resources in terms of facing global competition.

Due to the development and the management of RPTRA set on society's hand, it is giving an understanding that the future of our generation is on all hands of us, which mean the responsible is not only for the people in charge in education field but also belong to student's parents. Each of society class could collaborate in controlling also supporting the improvement of future generation resources. RPTRA also a space for society for meeting and gathering for any related positive activity.

One of the most issue facing by family related to education is, student who are lazy to going to school. Beside the curriculum factor, another dominant factor comes from student's internal side. Most of student do not understand the relevance of going to school and their future profession. Sometimes, parents also do not understand the reason of student laziness for going to school, in other hand most of parents push their child in a wrong way by telling them what to achieve in school without making them understand what is the most important target of education itself. It brings a bad impact for the growth of student's psychology. Besides, parents less knowledge toward the importance of school equal with student less motivation of school process. In some of student's opinion, they are going to school just as a responsibility to making their parents happy, not for the real target of education itself. Eventually for sure they have blur understanding about school could be their ladder into their future profession.

There are 5 factors caused student laziness of going to school, which are : inappropriate learning style, unsupporting surroundings, bullying, failed learning process, emotional distraction (Djie, 2019). Laziness of going to school have intrinsic and extrinsic factor. The laziness raised because there is no self motivation, not understand the goal yet, or there is no target yet from and for themselves (Maulidia, 2008). One of the 9 factors that is causing weakness of education development in Indonesia is the low relevance of education and the primary needs, especially in related of skill when entering the working place (Suroto, 2014: 498).

Based on the research results of non profit institution in UK, Education and Employers, who made a survey of some of country which is including Indonesia is the most mentioned profession by student are police and doctor; $58 \%$ male student and 12\% female student chose police; almost $69 \%$ female student chose doctor and another $12 \%$ chose teacher. $20 \%$ of all chose the profession due to knowing someone who having their chosen profession, 90\% knowing the profession through television/movie/radio and only 5\% admit that they know the profession from someone they met at school (Chambers, Kasherfpakdel, Rehill, \&Percy, 2018 :63). There are so many supporting researches that stated how important self motivation and surrounding in order to understand the reason and target of school related to future needs.

Author brings an interest to giving a contribution for sharing the understanding and inspiration of future profession to the student and their parents about the school's benefit. What its mean by benefit is the target of the 
education as our primary needs that need to be well prepared for student so they could be someone who have a certain skill and making themselves ready to facing and competing in future working place. If the related information transferred by kind of lecture method, RPTRA is going to be a boring stuff.

If the information media function well, then the interesting information might be understood well. In other words, the layout of information media that does not have sufficient design will be useless (Wardhani \& Soedarwanto, 2019). Author also believes a creative activity which raising student attention and interest, is going to be fun and playful. But unconsciously it helps to shaping the student's positive perception in terms of improving student's motivation about going to school. Also, it could be a playful activity in their free time of the online class phase during Covid-19 pandemic.

\section{THE IMPLEMENTATION METHOD}

Refer to the described issues above, author brings a solution. However, the factor of student's laziness of going to school are:

1. Have no dream and have no clear objective about school and its relevance with personal hobby in terms of supporting their future profession

2. Have no self confidence and have no surrounding's support, so they are afraid of being bullied.

3. Difficulties of socializing and communication, so they could not share their challenge at school. Based on above points, author gives a solution in the form of activity which could inspire and motivate student learning eager. This activity used methods that used by Education Employers in UK by coloring the future profession. However in this activity, author added the concept of creative interaction, so student are able to presenting their future profession to others, such as friends or family as well as giving a strong imagination in order to instill the value on their memory for a long term. By this activity the student could build their confidence, aware of their strength from their own hobbies, also being open of sharing their thoughts about their future profession to their closest surroundings who are family and friends. Furthermore, if the student could set what is their future profession and aware why they choose it, eventually it raises their motivation to going to school.

According to Kids Country Learning Centers, there are 6 goods of coloring activity for child, as: support fine motor skills, stimulate visual analysis, build concentration. Increase hand and eye coordination, lift confidence, train to solve problem creatively (Kids, 2019). By the coloring activity, the student could have more concentration towards one thing, and lift their self confidence, in terms of their chosen future profession. Furthermore, coloring also help student for expressing themselves.

Future profession decision greatly influenced by the model of the student closest family, as well as intensive role by their mother in making a future plan (Palos, 2010). Refer to that, the activity involves student and their mother to be together in RPTRA, mother must be able to make an interaction while the student coloring the picture of their chosen future profession so it could be a kind of their personal dream board. Through the interaction, unconsciously it builds support that are going to lift their self confidence in terms of decide their future profession. Also, open a communication among mother and child about their feeling, their needs, and what is the target of their chosen future profession.

There will be a try out of this activity at RPTRA Meruya Selatan. On the try out activity, the student will be interviewed about their related future profession and their future chosen major study. Should student could mention and explain about their future profession at the end of try out activity, means the activity hold a significant impact to motivating student for going to school. It is guaranteed because the student own the responsibility since their early age about the reason they are going to school which is for entering their chosen major study that eventually for achieving their chosen future profession. By above experience, positive perception about the importance of going to school being shaped in order to achieve their target.

The method used are : 
1. Qualitative / Descriptive Method

Facilitator will explain 3 kind of profession to the student through the coloring book. The explanation is about any certain skill needed, the contribution to the society, and the general working procedure in actual life. It will done by descriptive skill such as telling them about what uniform they should wear, and how should the nuance of the working place. Should the student could describe more detail by certain quality about supporting stuff regarding their chosen future profession, then it makes the profession being real and raising student cognitive awareness. Decorating and coloring their coloring book eventually comes as a fun activity and motivate them to finish the given task during the activity.

2. Presentation and Role-play Method

The student are going to straightly present their chosen future profession by telling others about their reason of choosing it and how sure they are about their strength. It also create a positive responsive by listening other student presentation which is open their mind if any possibility of different opinion told by others. The student also being asked to acting their future profession to stimulate their self confidence.

3. Question and Answer Method.

Student and their mother will have a question and answer session related to their future profession. The question is about the student hobby, their strength, and the reason of their decision, also about the positive influence of their future profession to society. This method must be hold smoothly so mother has to be more aware about their child opinion by listening more and give response only about the general step to achieving that profession. During this method, mother also has to show their appreciation should their child could achieve that profession in the future.

Three methods above should be held in gradually and continuously which mother as the mentor has to accompany their child during the activity. Furthermore, mother must always remind their child about the future profession even when they are at home, especially should they lost their motivation to going to school.

The illustration they colored, should be hang on their house wall so it is being eyecatching which is unconsciously will be saved into their long term memory. It is also raising a responsibility to achieving the profession by being a great student at school every day.

The mechanism of activity's evaluation: design an illustration book which the scheme related to the issue and solution planned, book distribution, try out activity, and book evaluation towards the activity achievement.

\section{RESULT AND STUDY}

\section{Illustration Book Scheme Design Process Plan}

Covid-19 pandemic issue changing people daily habit in Indonesia. High daily routine movements change in to from home kind of acitivity. School and work from home.

It is raising a new issue in society, particularly the smallest one who is family. All the family members suddenly take a part in school process. The community service program previously was a kind of face to face activity which then author changed in to a new idea by design an illustration book. However, the quality and objective of the activity stay same with the previous program. Author collaborate with involved students (college student) and also the person in charge of community service program from the university so the program itself could continuously being applied in order to giving a contribution to the society where is at RPTRA Meruya Selatan.

Social distancing rule applied during the pandemic is the reason why the illustration book comes instead of face to face activity. The illustration book will be given to RPTRA Meruya Selatan. The book could be a tool for parents, particularly mother in order to motivate their child at home in terms of school from home. Mother psychologically involved for building their child motivation of being focus even study from home.

The book is useless if mother was not able to accompanying their child while coloring it. The main idea of this book is open a space among the student and their mother to communicate about their future. 
The book have 3 parts : First, introduction which parents finding what is their child's desire profession. Then, the content part which raising a positive perception of the chosen future profession. And the last part which about affirmation and general step that student have to know in order to achieving their future profession.

The book filled with illustration that could be used by mother while accompany their child coloring it. The profession showed on this book is a kind of low interest profession but been popular nowadays at society which for sure will still exist in their future.

This illustration book is one of solution for society in order to help parents presenting various profession which also a kind of fun creative activity to do during the pandemic. It is fun because the color itself improve student brain's work. Coloring process unconsciously influence their mind to remember their chosen future profession in the long term.

\section{Illustration Book Design Implementation.}

This illustration book design referring to journal wrote by Matindas, an expert of student resources management who stated that student's creative process during learning session will showing a desire and motivation for finding an answer as a part of achieving a certain understanding (Matindas, 2002;71-72; Pramartasari, T.Marpaung, \& Achmad, 2018).

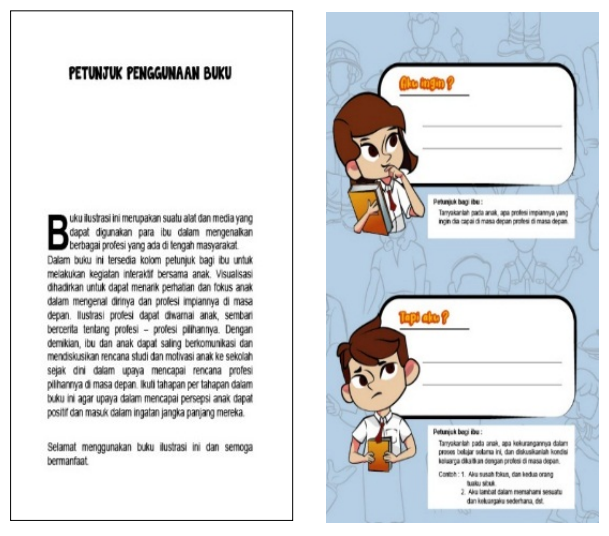

Figure 1. Book Instruction and Concept of AKU

(Source :Ghazy, 2020)

Matindas concept of A.K.U is stands for Ambisi (ambition), Kenyataan (Reality/Condition), and Usaha (Effort) which use during the book scheme design process. The objective is to shaping student's positive perception towards future profession that eventually will improve their motivation of following their school routine activity.

The title of "I Am Going To School Because I Want To Achieve My Future Profession" is a kind of affirmation as well as the objective of the book. The illustration of students wear elementary uniform with a bright smile on their face stimulate the student interest about happiness of going to school. It is also personally deliver a message of being grateful should they face changes and challenges in the future

The illustration itself also presenting how proud they are wearing their school uniform. It's target is for raising the appreciation which is a kind of positive perception about the good things they will get from their education at school is for themselves not others. In case the laziness comes, then the feeling of shame and sorry also comes up for themselves. Because most of the fact, should the laziness comes, it is the parents who feel the shame and sorry due to they paid school fee already, meanwhile the student are not aware about their lost.

That is the main failure caused a misscomunication among parents and child. If three illustration above could apply gradually, as wel as a honest communication among them, it will raise the positive perception of the importance of going to school. There are 15 of profession illustration designed on the book. Each illustration have a symbol or design that is related to the profession itself, such as the attribute or how the society opinion about the profession. All of the illustration should be described by their mother use an interactive descriptive 
method while encourage the student to coloring it creatively. The student allowed to adding more visual design or symbol to complete or stimulate the realness of their imagination towards the profession.

\section{Illustration Book Using Steps.}

This illustration book is a tool and media for parents, particularly for mother in terms of introduce various of profession, especially the nowadays profession but the parents not really aware of. On this book, there are instruction column for mother so they could do the interaction in every illustration provided. First, the book using steps starts from the title "I am going to school because I want to achieve my future profession" which mother has to explain that inside the book the student will find a profession their child could achieve should they are good at school. The parents have to digging their child opinion, so parents could help their child to achieve it. Meanwhile coloring step is up to the student.



Figure 2. Book of "I am going to school because I want to achieve my future profession". Books are ready to distribute to RPTRA Meruya Selatan.

(Source :Ulita, 2020)

Second step is parents start a discussion about the concept of A.K.U. Parents have a role to create a two ways communication by asking what is their child desire of future profession. Then parents explain their child about their chosen profession as well the relevance with their family situation, so the student could fill "But I..." as a picture of their weakness or their family weakness. Then parents ask the student to make a simple step they could do to achieve their future profession considered of their weakness or limit.

Third step is parents play the role to transferred the understanding of each profession to their child. They are able to coloring the illustration starts from the most liked profession to motivate them finish the rest illustration.

Last step is parents encourage the student to reading the content about "Now I Know, I Must". It is have to be done in order to improve student awareness and motivation in learning process at school.

\section{The Power of Visual for Shaping the Positive Perception about Student's Future Profession.}

Based on the research results of non profit institution in UK, Education and Employers, who made a survey of some of country which is including Indonesia is the most mentioned profession by student are police and doctor; $58 \%$ male student and $12 \%$ female student chose police; almost $69 \%$ female student chose doctor and another $12 \%$ chose teacher. $20 \%$ of all chose the profession due to knowing someone who having their chosen profession, 90\% knowing the profession through television/movie/radio and only 5\% admit that they know the profession from someone they met at school (Chambers, Kasherfpakdel, Rehill, \&Percy, 2018 :63). There are so many supporting researches that stated how important self motivation and surrounding in order to understand the reason and objectives of school related to future needs.

Should student been introduced about various profession option using visual learning which is implementation of illustration and illustration coloring, it must improve their analysis ability in terms of the learning process they have. The improvement of analysis ability will stimulate student about good visual perception which also have a positive impact to the socializing ability. Should the student have the information about various profession in their early age, it is also building a positive perception towards their chosen future 
profession which improving their motivation to finish their school so they could entered college to specifically improve their skill in order to achieve their future profession. At least Indonesian student know more about profession, not only about police, doctor, or teacher. However, it needs support from their closest people such us, teacher, parents (mother) and friends.

\section{Try Out Acitivity}

This illustration book is a tool and media for parents, particularly for mother in terms of introduce various of profession, especially the nowadays profession but the parents not really aware of.

Refer to try out on 2020, $21^{\text {st }}$ August, which is involved 2 mothers and 2 students, as following:

1. Mrs. Afifah and Irsyad ( $5^{\text {th }}$ grade of elementary school )

2. Mrs. Emi and Daffa ( $6^{\text {th }}$ grade of elementary school )

After the try out, the team asked the mothers feedback about the book. The feedback could be an advice in order to make this illustration book better and achieve its target.

According to Mrs. Afi, this book made her knowing her child dream and made her aware about challenges they are going to face. By the coloring activity, the communication being more detail and personal. Mrs, Afi acknowledged her child having a dream to be a youtuber which she never know before.

According to Mrs. Emi, this book made her knowing there a lot of "new" profession that she never aware of. This book open a interaction space about her child future and made her aware of the challenges in terms of achieving her child dream. By the coloring activity, the discussion ran fun and she could give color option too for the chosen profession.
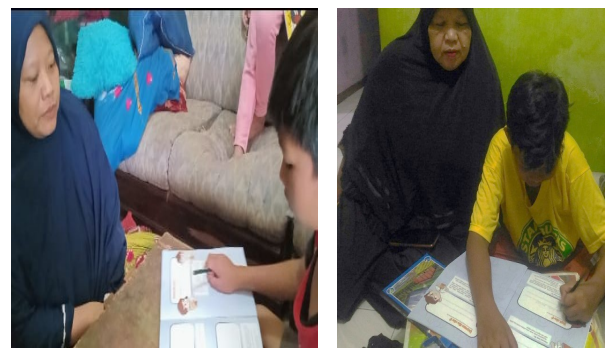

Figure 3.

Students were writing their future profession plan while listening to their mother's

The try out of this book held in order to acknowledge what is the challenges or weakness of this book, as following details :

1. Need more kind of profession, also specifically by series. Example, broadcasting series, sport series, etc.

2. Put an identity column and date column, so it could be as reference of next activity also as a memory.

After the try out activity done, the illustration book will be evaluated and improved so it could have more better result which the target is to encouraging student to go to school and aware of their future profession in their early age. This book also considered as community services program by visual communication design major study which will be given to RPTRA Meruya Selatan on 2020 August and will be held with support from Community Services Center of Mercu Buana University.

\section{CONCLUSION}

This community services program found 3 issues of the student, which are : having no goal and not aware of why they are going to school, low self confidence, difficulties of comunication and socialization. By 
this activity mother and their child could have an interaction, socialization, and sharing information about their chosen future profession while doing a fun coloring activity.

Illustration on the book try to instilling student's positive perception towards various profession that will be described by their own mother. Coloring stimulate student's brain work in terms of remembering their chosen future profession which motivate them to studying hard in order to achieving their dream. Mother's role is important in giving an advice, explain the step of how to achieve it, and remind the student continously about the future profession. Student have to aware of the importance of going to school is to achieving their dream instead of for their parents.

This activity will get a better results if supported by psycology's expert and education institution who would collaborate consistently focus on improving student interest and motivation by future profession introduction since the early age. It could expand the research and the main idea of making this illustration book in terms of giving positive contribution to society.

\section{BIBLIOGRAPHY}

Amelia, M. (30. Desember 2016). Berita. Abgerufen am 30. Oktober 2017 von Detik News: https://news.detik.com/berita/d-3384009/kapolda-metro-kejahatan-di-jakarta-terjadi-tiap-12-menit-18detik

Antony, N. D. (5. Juli 2019). News. Abgerufen am 18. Nopember 2019 von Detik.com: www.m.detik.com

Cayir, A. (2017). Analyzing the Reading Skills and Visual Perception. Universal Journal of Educational Research 5(7) DOI: 10.13189/ujer.2017.050704, 1113-1116, 2017.

Chambers, N., Kashefpakdel, D. T., Rehill, J., \& Percy, C. (2018). Drawing The Future. UK: Education and Employers.

CNN, I. (25. Oktober 2019). Nasional. Abgerufen am 18. Nopember 2019 von CNN Indonesia.com: www.m.cnnindonesia.com

Davis, J. (22. Juni 2015). Abgerufen am 19. Nopember 2019 von Learning4kids.net: https://www.learning4kids.net/2015/06/22/benefits-of-colouring-in-activities/

Djie, A. d. (22. Juli 2019). Artikel. Abgerufen am 18. Nopember 2019 von Sehatq.com: www. sehatq.com

Fahrudi, E. \&. (2016). Peran Pendidikan Sebagai Pondasi Penumbuhan Karakter Bangsa Indonesia. Prosiding Seminar Nasional Reforming Pedagogy (S. 333-336). Yogyakarta: Universitas Sanata Dharma.

Hendrian, D. (2. Mei 2016). http://www.kpai.go.id/. Abgerufen am 30. Oktober 2017 von Komisi Perlindungan Anak Indonesia: http:/www.kpai.go.id/berita/memprihatinkan-anak-pengguna-narkoba-capai-14-ribu/

Herawati, D. T. (29. Juni 2020). News. Von IPB University: https://ipb.ac.id/news/index/2020/06/perankeluarga-menjadi-kunci-utama-di-era-pandemi-covid-19-dan-newnormal/97065bf36bb764b8257e2b474ab6102f abgerufen

Joffe, H. (2014). The Power of Visual Material : Persuasion, Emotion and Identification. International Council For Philosophy and Human Studies October 2014, 84-93.

Kids. (21. Juli 2019). Abgerufen am 19. Nopember 2019 von Kid'sCountry: https://kidscountryinc.com/2016/07/21/6-benefits-drawing-time-children/

Kubovy, M., Epstein, W., \& Gepshtein, a. S. (2012). Experimental Psychology. Volume 4 in Weiner IB (Editorin-Chief) Handbook of Psychology, Edition: 2e, Chapter: Visual Perception: Theoretical and Methodological Foundations, , pp.85-119. Manhattan: John Wiley \& Sons, Editors: Healy AF \& Proctor RW. 
Maulidia, R. (2008). Problem Malas Belajar Pada Remaja (Sebuah Analisis Psikologis) . Jurnal Tsaqafah Volume 3 Nomor 2 , 129-144.

Nugrahani, R. (2007). Media Pembelajaran Berbasis Visual Berbentuk Permainan Ular Tangga Untuk Meningkatkan Kualitas Belajar Mengajar Di Sekolah Dasar. Lembaran Ilmu Kependidikan Jilid 36 No.1 Juni 2007, 35-44.

Nur Habibah Zain, P. W. (2013). Pengembangan Komik Bahan Ajar IPA Terpadu Kelas VIII SMP Pada Tema Sistem Pencernaan Manusia dan Hubungannya Dengan Kesehatan. Unnes Science Education Journal 2 (1) $2013,217-222$.

Palos, R. a. (2010). The Impact of Family Influence on The Career Choice of Adolescents. Procedia-Social and Behavioral Sciences Vol 2, 3407-3411.

Pramartasari, N., T.Marpaung, R. R., \& Achmad, d. A. (2018). Efektivitas Media Pembelajaran Monopoli Berbasis Assure Terhadap Kemampuan Berfikir Kristis Peserta Didik. Jurnal Bioterdidik Wahana Ekspresi Ilmiah Volume 6, Nomor 4.

Prodjo, W. A. (4. Mei 2020). Edu. Von Kompas.com: https://www.kompas.com/edu/read/2020/05/04/211943371/belajar-dari-rumah-antara-orangtua-gagapadaptasi-dan-anak-tak-senang?page=all abgerufen

Raiyn, J. (2016). The Role of Visual Learning in Improving Students' High-Order. Journal of Education and Practice www.iiste.org ISSN 2222-1735 (Paper) ISSN 2222-288X (Online), 115-121.Retno Puspitorini, B. S. (2014). Penggunaan Media Komik Dalam Pembelajaran IPA Untuk Meningkatkan Motivasi dan Hasil Belajar Kognitif dan Afektif. Cakrawala Pendidikan Oktober 2014 Th XXXIII No.3, 413-420.

Safutra, I. (18. Nopember 2019). Nasional/Pendidikan. Abgerufen am 18. Nopember 2019 von Jawa Pos.com: www.jawapos.com

Subarto. (2020). Momentum Keluarga Mengembangkan Kemampuan Belajar Peserta Didik Di Tengah Wabah Pandemi Covid-19. ADALAH, Buletin Hukum dan Keadilan, Volume 4 Nomor 1, ISSN : 2338 4638, 13 18.

Suroto. (2014). Kebijakan Pembangunan Pendidikan Nasional Indonesia dan Kendala Yang Dihadapi Sebagai Upaya Perbaikan Dalam Rangka Mempersiapkan Warga Negara Muda Yang Baik dan Cerdas. Jurnal Pendidikan Kewarganegaraan Volume 4, Nomor 7, 7 Mei, 495-499

Wardhani, A., \& Soedarwanto, N. U. (2019). The Socialization Of Visual Media Promotion On Ancol Youth Comunnity In Sunda Kelapa. International Conference On Comunnity Development Vol 2 No.1, 138142 